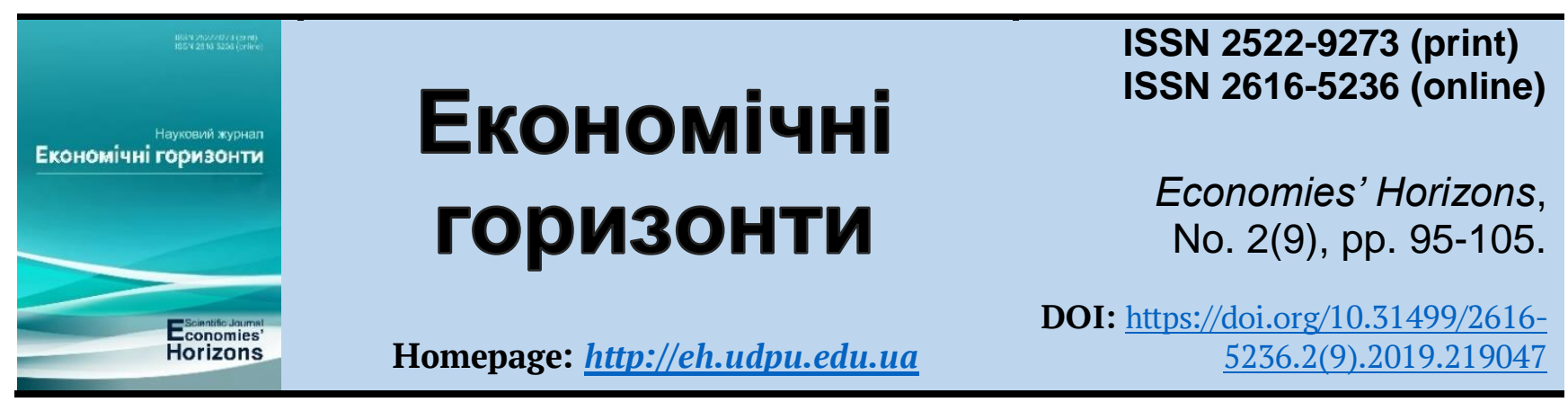

UDC 658.5:338.5

\title{
Methodology of forming and providing strategic economic interests of mining and metallurgical enterprises
}

\author{
Volodymyr Ya. Nusinov ${ }^{1}$, Doc. Ec. Sc., Professor \\ Ievgeniia V. Mishchuk ${ }^{2}$, Cand. Ec. Sc., Associate Professor
}

Received: 6 May 2019

Accepted: 7 June 2019

\begin{abstract}
Nusinov, V. Ya. and Mishchuk, le. V. (2020), "Methodology of forming and providing strategic economic interests of mining and metallurgical enterprises", Economies' Horizons, no. 2(9), pp. 95-105, doi: https://doi.org/10.31499/2616-5236.2(9).2019.219047
\end{abstract}

Abstract. The research objective. The article aims to develop the methodology of forming and providing strategic economic interests of mining and metallurgical enterprises. Methodology. The research uses such general theoretical methods as generalization, explanation, and clustering to analyze economists' and practitioners' ideas about the research object and summarize the results of content analysis of primary sources; analysis and synthesis to justify a new conceptual approach to business analytics in evaluating and providing security of strategic economic interests of enterprises. Results. It is taken into account that over the next five to ten years, the global mining and metallurgical industry will fundamentally alter under the influence of global trends. It is defined that the level of security of strategic economic interests of enterprises is influenced by the growth of requirements to products and by the corresponding growth in demand for innovation; transformation of business models due to changes in raw materials availability and requirements to environmental sustainability of products. It is revealed that a number of market factors provoke a weak growth in demand for products of mining and metallurgical enterprises. Apart from that, market factors are accompanied by trends in the industrial policy of foreign countries providing for the implementation of systemic measures to develop entire industries and restrict imports. On this basis, the methodology of forming and providing strategic economic interests of mining and metallurgical enterprises that considers global trends is developed. The list of main trends, according to which mining and metallurgical sub-industry will develop, is substantiated. The influence of these trends on economic security of enterprises is determined. A set of indicators to assess security of strategic economic interests of enterprises for each of the identified trends is suggested. Practical importance. Business analytics of the security science is further developed in terms of substantiating a number of indicators reflecting the extent of mining and metallurgical enterprises' readiness for future global trends: de-industrialization of the world economy, regional transformation of consumer demand, total digitalization of business processes, production decarbonization and carbon-free metallurgy. This managerial innovation allows implementing an integrated priority measures to ensure

\footnotetext{
${ }^{1}$ Kryvyi Rih National University; Professor at the Department of Accounting, Taxation, Public Management and Administration; ORCID ID: https://orcid.org/0000-0002-9293-2969; e-mail:vladimir.ya15@gmail.com

${ }^{2}$ Kryvyi Rih National University; Associate Professor at the Department of Accounting, Taxation, Public Management and Administration; ORCID ID: https://orcid.org/0000-0003-4145-3711; e-mail: tdutybz.077@gmail.com.
} 
strategic alignment of resources and processes with future parameters of business environment to retain / achieve the desired level of economic security in the long run. Further research is devoted to improving the methodology of defining requirements of enterprise's stakeholders to parameters of economic security that will define additional approaches to providing security of strategic economic interests at enterprises of mining and metallurgical complex.

Keywords: business analytics, economic security, strategic economic interests, forming, provision, global trends.

JEL Classification: H56, J28.

Number of references: 16; number of tables: 0; number of figures: 0; number of formulas: $\mathbf{0 .}$

\title{
Методологія формування й забезпечення безпеки стратегічних економічних інтересів підприємств гірничо-металургійного комплексу
}

\author{
Володимир Якович Нусінов ${ }^{1}$, д. е. н., професор \\ Євгенія Володимирівна Міщук ${ }^{2}$, к. е. н., доцент
}

Стаття надійшла: 06.05.2019 Стаття прийнята: 07.06.2019
Nusinov V. Ya. Mishchuk le. V. Methodology of forming and providing strategic economic interests of mining and metallurgical enterprises, Економічні горизонти, no. 1(12), pp. 95-105. DOI: 10.31499/2616-5236.2(9).2019.219047

Анотація. Мета дослідження. Метою статті є розробка методології формування й забезпечення безпеки стратегічних економічних інтересів підприємств гірничо-металургійного комплексу. Методологія. У дослідженні застосовуються загальнонаукові теоретичні методи: узагальнення, пояснення, групування - для аналізу поглядів економістів і практиків на об'єкт дослідження та формулювання висновків контент-аналізу первинних джерел, аналіз і синтез - для обгрунтування нового концептуального положення щодо бізнес-аналітики в оцінюванні й забезпеченні безпеки стратегічних економічних інтересів підприємства. Результати. Ураховано, що протягом наступних п’яти - десяти років світова гірничо-металургійна галузь принципово зміниться під впливом глобальних трендів. Визначено, що на рівень безпеки стратегічних економічних інтересів підприємства впливає зростання вимог до продукції підприємств і відповідний цьому ріст попиту на інновації; перетворення бізнес-моделей через зміни в доступності сировини та вимог до екологічності продукції. Виявлено, що ряд ринкових чинників провокують слабке зростання попиту на продукцію підприємств гірничо-металургійного комплексу. При цьому до ринкових чинників додаються тренди у промисловій політиці зарубіжних країн, що передбачають реалізацію системних заходів щодо розвитку цілих галузей промисловості та обмеження імпорту. На цій підставі розроблено методологію формування й забезпечення безпеки стратегічних економічних інтересів підприємств гірничо-металургійного комплексу, яка базується на врахуванні глобальних трендів. Обгрунтовано перелік основних трендів, відповідно до яких розвиватиметься гірничо-металургійна підгалузь. Визначено вплив цих трендів на економічну безпеку підприємств. Запропоновано сукупність показників для оцінювання безпеки стратегічних економічних інтересів підприємства за кожним виокремленим трендом. Практичне значення дослідження. Отримала подальший розвиток управлінська бізнес-аналітика безпекології в аспекті обгрунтування сукупності показників, які відображають ступінь готовності гірничо-металургійних підприємств до майбутніх глобальних трендів: деіндустріалізація світової економіки,

\footnotetext{
${ }^{1}$ Криворізький національний університет; професор кафедри обліку, оподаткування, публічного управління та адміністрування; ідентифікатор ORCID: https://orcid.org/0000-0002-9293-2969; e-mail: vladimir.ya15@gmail.com.

${ }^{2}$ Криворізький національний університет; доцент кафедри обліку, оподаткування, публічного управління та адміністрування; ідентифікатор ORCID: https://orcid.org/0000-0003-4145-3711; e-mail: tdutybz.077@gmail.com.
} 
регіональна трансформація споживчого попиту, тотальна діджиталізація бізнес-процесів, декарбонізація виробництва та безвуглецева металургія. Така управлінська новація дозволяє формувати пріоритетний інтегрований набір дій по забезпеченню стратегічної відповідності ресурсів та процесів майбутнім параметрам бізнес-середовища задля утримання / досягнення бажаного рівня економічної безпеки у довгостроковій перспективі. Подальші дослідження автора присвячені удосконаленню методики визначення вимог стейкхолдерів підприємства до параметрів його економічної безпеки, що визначатиме додаткові підходи до забезпечення безпеки стратегічних економічних інтересів на підприємствах гірничо-металургійного комплексу.

Ключові слова: бізнес-аналітика, економічна безпека, стратегічні економічні інтереси; формування; забезпечення; глобальні тренди.

Кількість джсерел: 16; кількість таблиць: 0; кількість рисунків: 0; кількість формул: 0.

\section{Introduction.}

The topicality of the enterprise's economic security issues results in scholars' paying more attention to achieving / retaining its desired level in terms of forming and providing economic security in general and its individual subtypes in particular (Mishchuk, 2018). Current global recession makes enterprises focus on economic security formation on the basis transformational shifts in the structure of sales and supply chains. At the same time, present conditions of business environment characterized by unclear causation and nonlinearity, make it impossible to provide effective economic security solely by countering threats and risks. Opportunitybased proactivity is gaining priority. Based upon the up-to-date definition of a strategy as an awareness of an enterprise's place and role in the future flow of badly predictable events, the content of security of strategic economic interests of enterprises is defined as a subtype of economic security being formed now in respect to the context of the future. Security of strategic economic interests is characterized by both resistance to risks / threats and the extent to which opportunities in the future flow of events are considered. This establishes the information basis for developing and implementing an integrated set of managerial steps aimed at achieving and retaining the desired level and state of economic security in the long run. Accordingly, formation and provision of strategic economic interests should be based on the vision of the future, which is not identified as prediction, but is a view of a current level of economic security and a means to achieve / retain its desired values from the future perspective. This creates a new context for the perception of the present and gives the answer to the question: what should be done today to provide the desired level of economic security in the future?

\section{Problem setting.}

Smoothing the impact of uncontrolled business environment factors at mining and metallurgical enterprises determines the utmost importance of short- and medium-term opportunities, which, in our opinion, are as follows:

- stockpiling that enables accumulating reserves of finished products to meet growing demand after the end of the pandemic;

- oil price downturn that results in reduction of freight rates and allowing national producers to focus on the markets of Asia, one of a few regions where demand has already begun to recover;

- increase in domestic demand due to implementation of governmental programs on motorway reconstruction, development of port and railway infrastructure, construction of regional airports;

- promotion of supply chains and breaking into new target markets through M\&A agreements, which ensures consolidation of the industry and counteracts trade restrictions; 
- technical re-equipment within existing technologies and introduction of the Industry 4.0 toolkit (artificial intelligence, the Internet of Things, smart devices, smart modeling, creation of a single information management environment, etc.) to reduce material and energy consumption of products;

- expansion of a customer base by increasing the degree of personalization - offering a unique range specification for each customer;

- application of bimodal supply chains as a combination of two logistic "modes": the first (traditional) one focuses on lean efficiency, low risk and high predictability; the second one provides for the fast change, responsiveness and situationality in decisionmaking under unforeseen circumstances.

Thus, under such conditions, economic security can be formed and provided only by implementing the measures that consider current global trends of the industry and world development in general.

\section{Literature review.}

Economists use the concepts "the mechanism of economic security provision", "the mechanism of economic security formationt" and "the mechanism of economic security management" as equivalents in majority of research papers (Lebedko, 2017).

O. Liashenko (2015) emphasizes the expediency of a scientific approach to economic security management, not its provision, explaining that the latter is also a consequence of economic security understanding as a state or characteristic, as well as the evolution of enterprise management goals: "although in the 1990s a goal of enterprises was to ensure their economic security, i.e. the protective function of management took place, in the early 20th century that function became purely managerial and administrative" (hereinafter courtesy translation); at the same time, economic security management is a precondition for existence of the enterprise in time and space as a socio-economic system.

S. Lebedko (2017) studied and systematized the existing definitions of "the mechanism of economic security provision" and "the mechanism of economic security formation" which in his opinion define different types of mechanisms for managing economic security. He also figured out a conceptual difference between them, namely their different functions:

- when using the mechanism of economic security provision, the achievement of its target level is accentuated;

- when using the mechanism of formation, the emphasis is on creating secure operational conditions.

I. Chumarin (2003) reconciles a matter of economic security provision of enterprises with the theory of survival and connects it with the problems of their functioning in transition periods under conditions of nomenclature and output fluctuations, and with the financial situation of suppliers and consumers. However, modern realities supported by the scientific evidence base show that formation and provision of economic security at all levels of its hierarchy should accompany the entire lifecycle of products, all cycles of regional and state development. Moreover, I. Chumarin paid special attention to the impact of the financial situation of the enterprise's suppliers and consumers on its economic security. Although it is expedient to supplement this list of stakeholders with all their groups, both internal and external ones.

Having analyzed research papers on strategic economic security, the idea of decisionmaking on economic security provision only to ensure short-term benefits and strengthen standing appears to be incomplete (Chumarin, 2003).

As for setting goals of security of strategic economic interests, lack of a single approach among both foreign and national researchers should also be noted. The most common approach is to single out one global goal, but not to elaborate them. Papers of many researchers from post-Soviet countries illustrate this approach, e.g. V. Tambovtsev (1994; 1995): "economic security of any system should be understood as a set of characteristics of its production subsystem which provides the 
ability to achieve the goals of the whole system". However, there is an approach according to which goals of economic security are divided into main and secondary ones. Thus, according to I. Chumarin (2003), the main goal of economic security is to achieve maximum stability and create a basis and prospects for growth to meet goals of a business unit regardless of objective and subjective risk factors.

Based on the conclusion made by $\mathrm{O}$. Liashenko (2015), the hierarchical approach to defining goals of both economic security, and security of strategic economic interests is considered to be inexpedient. Namely, the researcher noted that economic security management of enterprises should have a clear direction having such benchmarks as the enterprise's survival, threat protection, and stability or development which should not be considered using the hierarchical approach as the sequence of appearance and disappearance of vectors of this direction can be random and unique for each enterprise. Indeed, for the same specific system, the characterization of its state as economically secure depends on its desired future: if, for example, an enterprise seeks only to stand out competition, then sales decline can be considered as quite secure; if its goal is to expand its niche on the market, then such a decline is a clear threat, and the current state of the enterprise can hardly be called secure (Tambovcev, 1994; 1995). However, in the same paper, O. Liashenko (2015) points to the hierarchical goals of economic security management of the enterprise and their consistency at each level of the hierarchy to align the interests of the enterprise's internal environment.

Analysis of interrelation between security of strategic economic interests and development of the enterprise holds a significant niche in research. Thus, defining economic security, T. Suhorukova (1998) mentions that economic security is not only a set of measures to counter threats, but also the ability of a system to implement these measures and ensure sustainability and achievement of goals. The reason for economic security provision is also widely studied. In particular, O. M. Liashenko (2015) believes that the enterprise's economic security is to be achieved for its development which is one of the vital interests, while anticipatory reaction to threats to the enterprise's interests being immanent in its development is an essential feature of economic security.

Apart from that, the research literature uses individual concepts: "formation of economic security" and "formation of the economic security system". The study by T. Hrynko and L. Lysenko (2014) shows that there is no clear common classification of factors forming economic security, and most economists do not classify them by certain features at all. Factors of forming a set level of the enterprise's economic security are not only diverse; they have their own specificity depending on the industry. However, there are general, typical factors that affect the enterprise's economic security level regardless of the ownership type and industry (Kurhuzenkova, 2016).

The widest, from our point of view, is the definition of a mechanism of economic security formation given by N. Biloshkurska (2013): "a combination of goals, tasks, principles, methods, functions, means for making adaptive decisions on enterprise development". Yet, the explanation by P. Putsenteilo and O. Humeniuk (2017) is of scientific interest as well. According to them, economic security is the enterprise's state to be retained if it ensures: protection of its interests in general, as well as of its owners, management and employees; resistance to internal and external threats; the ability to develop; progressive development of staff competencies and use of the enterprise's resources. Besides, the researchers also believe that a system of economic security of the enterprise is a set of elements protecting a multilevel pyramid of economic security objects the basis of which is physical infrastructure, staff and resources (Putsenteilo, $\mathrm{Hu}$ meniuk, 2017). 
Problems of ensuring economic security are also relevant for foreign scientists. However, if among Western studies the overwhelming role is assigned to household security (The Aspen Institute, 2018; Ajdari and Asgharpour, 2011), then Eastern scholars focus more attention on the country's national security (Tamošiūniene and Munteanu, 2015). For Western economists on the safety of companies, it is more typical to apply the concept of risk management (Giannopoulos, Filippini, and Schimmer, 2012). The ways to ensure the economic security of businesses and companies have begun to be explored more thoroughly over the past thirty years. This was facilitated by both global and local (within one country) financial crises, the consequences of which affected the activities of all business entities (Ianioglo and Polajeva, 2016).

Thus, we believe that one of the main directions of economic security formation in general and security of strategic economic interests in particular is its evaluation and provision taking into account changes in the external environment of the enterprise.

\section{Methodology.}

The research uses such general scientific theoretical methods as generalization, explanation, clustering to analyze economists' and practitioners' ideas about the research object and summarize the results of content analysis of primary sources; an analysis and synthesis to justify a new conceptual ideas of business analytics in evaluating and providing security of strategic economic interests of the enterprises.

\section{Research objectives.}

The article is aimed at developing a methodology of forming and providing security of strategic economic interests of mining and metallurgical enterprises.

\section{Results and discussions.}

The key trends in the development of both world economy in general and the mining and metallurgical industry in particular provoke unprecedented changes in technological solutions and requirements of stakeholders. The main characteristics of the specified trends with the suggested indicators for assessing their impact on the level of strategic economic security of the enterprises under study are given below.

The first trend is the deindustrialization of the world economy and regional transformation of consumer demand. Forecasts of experts indicate a slowdown in global economic growth in the long run to $3.2 \%$ per year. Undoubtedly, this will adversely affect the market of mining and metallurgical products, and the predicted growth rate of its future consumption are minimal.

Population and urbanization growth leads to construction boom consuming $50 \%$ of steel. However, these opportunities are partially offset by the trends of total deindustrialization of the economy, as such, during 19942018 a share of industry in the global GDP decreased by 8 percentage points to $25.4 \%$. Further on, this trend will deepen exponentially due to: reorientation of the economy of developed countries to service production, i.e. to development by means of the least metal-intensive industries; scaling of the "Industry 4.0" toolkit, which requires a much smaller amount of steel per $\$ 1$ of output.

Thus, economic security provision of national mining and metallurgical enterprises lost its linear relation between consumer demand and population and the world economic growth. Transformational regional changes in consumer demand must be considered in case there are possibilities to generate cash flows through output and sales increase. Thus, the global population growth will occur due to 9 countries only, they are: India, Nigeria, Pakistan, Congo, Ethiopia, Tanzania, Indonesia, Egypt and the USA, while the population rate in Europe will remain almost the same in the next 30 years. As such, we note that the opportunities for economic security provision of national mining and metallurgical enterprises include export expansion at promising markets of Sub-Saharan Africa, Central and East Asia. Such changes expand the range of indicators for assessing economic security management efficiency of mining and metallurgical 
enterprises at the strategic level with the indicators of promising markets' development rate. In this context, an important indicator of assessing security of strategic economic interests is the ratio of sales at promising markets in the current period to the value of a similar indicator in the base period.

The second trend is applied total digitalization of basic business processes at mining and metallurgical enterprises. Critical transformation of the role and essence of these processes should be accentuated. In recent years, they have been a means of increasing enterprises' efficiency and created certain advantages, while in future they are going to become an objectively required prerequisite for providing economic security of mining and metallurgical enterprises, this fact being conditioned by the following:

- increased importance of optimizing operational costs as a means to accumulate cash flows in case of increased supply of iron ore products from the global mining companies conducting their operations in favourable mining and geological conditions with slowed metal consumption rates and volatile prices for raw materials;

- effects of Industry 4.0 tools scaling ;

- possible creation of a critically new platform to make managerial decisions and expand a management toolkit;

- formation of a single information landscape to combine industrial systems with business applications and enable creating a single cycle of planning, control, accounting and analysis of enterprises' activity while reducing the time period of managerial responses to internal and external changes.

In spite of the above advantages, digitalization of the enterprises under study will result in improving the industrial security level; enhancing mobility of supply chains; increasing levels of capacity usage; improving composition of charged and consumable materials. The global industry is currently experiencing accelerated digitalization including robotic au- tomation, the industrial Internet of things, BigData, digital alter egos, etc. Yet, professionals indicate a low average digitalization index of mining and metallurgy in spite of expotential increase in digital tool application, which is typical not only for developed countries, but also for post-Soviet ones.

However, Ukrainian mining and metallurgical enterprises are not Industry-4.0friendly, this causing threats to their future existence. Accordingly, under limited possibilities of extensive increase and relative technological conservatism of the industry, digitalization is essential for creating prerequisites to provide economic security of mining and metallurgical enterprises in case of increased supply and minimally grown demand for their products. At the same time, managers of mining and metallurgical enterprises should realize that the rate of changes is proportionate to business security. Thus, experts from Pricewaterhouse Coopers International Limited (PwC) accentuate that application of digitalization technologies becomes a typical feature of global mining and metallurgical enterprises ensuring their activity and security.

Considering the above, a conclusion may be drawn that the level of an enterprise's digital maturity is one of the key strategic indicators of efficient management of economic security. In terms of the complex character of the indicator, substantiation of its components is of great importance, namely:

- digitalization of a value chain involving creation of a parallel chain of digital models - duplicates that combine the virtual and the real-life worlds and are a precondition for operative, effective and target-oriented managerial actions. Within this framework, the ratio of the number of business processes with digital analogs to the total number of business processes of the value chain is an essential indicator;

- digitalization of equipment. Specialists of mining and concentration enterprises note that creation of replicas of certain units 
enables correction of their maintenance schedules and their effective use, while each change of an object is duplicated in its digital version. The virtual duplicate also enables modelling any impact which is urgent in case of changing resource supply, periods of unstable demands for products and other factors. In this context, the ratio of the number of machines at an enterprise with digital analogs to the total number of machines is an important indicator;

- digitalization of the raw material base enables reduction of mineral mining costs, improvement of geological and engineering steps of deposit mining starting from drilling operations to extraction of hard-mined ferruginous quartzite, creation of an information-analytical base of physical-chemical and mechanical characteristics of ore deposits, visualization of productive strata, analysis of alternative plans for mining operations online. The ratio of the number of digitalized sites to the total number of deposits is the key indicator here;

- the level of BigData application is the major driver for increasing efficiency of industrial systems. Yet, this factor is of special importance for mining and metallurgical companies operating tera- and petabytes of data on composition of charged materials, temperature modes of smelting, physical and chemical properties of alloys, etc. Introduction of BigData projects enables stating their great impact on parameters of mining and concentration including $12 \%$ reduction of ferroalloy consumption in steel production, $7 \%$ reduction of power consumption, $23 \%$ increase of productivity of rolling-mill machinery, $18 \%$ reduction of expenses for scrap metal collection. With this, it is expedient to apply the ratio of used methods of processing unstructured data to the required number of methods of processing unstructured data in order to assess security of strategic economic interests of an enterprise.

The total indicator can be determined as an arithmetic mean of the four indicators mentioned above.

The blockchain technology guarantees payment, accelerates business processes of product shipment and optimizes expenses caused by monetary transactions. That is why, one of the resulting indicators of forming and providing strategic security should be that of product promotion digitalization as an averaged value of the following two ratios:

1) the ratio of product sales based on global platforms in the assessed period to the total product sales in the assessed period;

2) the ratio of product sales when using the blockchain technology in the assessed period to the total product sales in the assessed period.

Introduction of the Industry 4.0 toolkit critically changes the ecosystem of suppliers of mining and metallurgical enterprises from the traditional (mechanical/automated machine maintenance, supply of fuel-lubricating and other consumables, etc.) to hi-tech ones represented by IT companies, big-data analysts, servicing companies of unmanned and robotized machines, etc. Considering this, the resulting indicator of economic security management as the level of suppliers' processibility is acquiring greater importance. In a similar way, one should consider indicators of the processibility level of other stakeholder groups consumers, financial and credit institutions, etc. 4.0 competences are becoming increasingly important for enterprise personnel.

Intensification of the role of digital technologies in mining and metallurgy conditions special attention to problems of cybersecurity. According to the above mentioned, cybersecurity of enterprises is becoming essential, objectivity of this indicator being based on a set of expert opinions of both external and internal professionals of the enterprise.

The third trend is associated with increased risks of environmental and climatic changes. Nowadays, decarburization is a global trend activated by consumers' demands and supported by state regulators. In general, Europe is about to transit to carbon-free production of steel. Undisputedly, this will contribute not only to the global warming fight, but also to technological revolution in the world metallurgy. On the one hand, Ukrainian metal producers, the engineering and 
technological level of whom is critically low, possess limited capabilities of transiting to carbon-free metallurgy. On the other hand, Ukraine is unable to stay aside from these processes implying implementation of the following two stages. The first stage is introduction of $\mathrm{CO}_{2}$ emission monitoring from 2021 according to draft law \#0875 "On basic principles of monitoring, reporting and verification of greenhouse gases", formation of the standard base by the Ministry of Green Energy to monitor emissions, actual monitoring being planned to commence in 2021. The second stage is introduction of quota trade for greenhouse gas emissions on the basis of the mentioned "Law on environmental monitoring".

As for the second stage, it is worth mentioning that there is the Emissions Trading System in the EU (EU ETS) that controls carbon dioxide $\left(\mathrm{CO}_{2}\right)$ and nitrogen oxide $\left(\mathrm{N}_{2} \mathrm{O}\right)$ emissions. The EU ETS system is the world largest trade system of carbon quotas making $75 \%$ of sales on this market. This involves the following stages. First, mining and metallurgical companies receive free emission limitations, which are reduced as time goes on. In case of emission overlimits, companies have to buy additional quotas on the open market, yet when some quotas remain unused due to implementation of some environmental steps, a company is able to sell them. In Ukraine, the required implementation of EU directives in the environment protection sector determines expediency of expanding managerial analytics of mining and metallurgical enterprises through applying the following indicators:

- the level of unused free limits for carbon emissions: the ratio of used limits to the total of free limits;

- profitability of sales of unused environmental quotas: the ratio of difference of sold environmental quotas and their price to that of enterprises' quotas;

- others.

Observance of fair amounts of environmental quotas by metal producers is another trend based on environmental barriers for metal product import to EU countries. In this context, it is worth mentioning that for Ukrainian metal-producers, the EU market is the major one making $35 \%$ of sales. The difference in emission costs will cause additional expenditures of $\$ 40$ per ton of steel. Besides, this will make export of Ukrainian semi-finished products impossible, as this product type has no such margin. Special attention should be paid to the fact that export of semi-finished products averages to $30 \mathrm{M}$ t/year. The difference in emission costs as well as global redistribution of trade flows will affect the economic security of the Ukrainian metallurgy, this being accompanied by intensified competition and reduced prices outside closed markets. Yet, prospects of growing environmental quotes do not end here: at present, the IMF recommends to increase the $\mathrm{CO}_{2}$ emission tax. Nowadays, Ukrainian companies pay $\$ 0.4$, while in future this will make $\$ 25$ per ton according to the IMF recommendations for developing countries. This means that with absent financing mechanisms for environmental steps, the idea of economic security becomes unrealizable, particularly from the strategic viewpoint.

Carbon-free metallurgy is becoming a new technological trend determining companies' potential in this context. The EU climatic policy aimed at reducing carbon gas emissions will make metal-producers gradually refuse furnace and converter production. Thus, the Swedish SSAB is going to commence carbonfree steel production in 2026 and withdraw from using coke / coal at its facilities in the USA, Sweden, and Finland by 2045. Hydrogen produced by HYBRYT technology developed in 2016 can replace unrenewable energy sources. The technology is based on iron reduction from ores by using hydrogen used later in the process chain in electric arc furnaces. Liberty Steel, ArcelorMittal, Voestalpine, ThyssenKruppe support the ideas of carbonfree steel production. Similar process projects are scaled. In January 2018, the Austrian Voestalpine declared development of a similar project on hydrogen metallurgy. The EU is 
investing 18M euros until 2021, this enabling studying potentials of hydrogen application to various stages of steel-making.

Considering the above-mentioned, a set of resulting indicators to assess the economic security level is expedient to be complemented with the following:

- expenditures for design operations aimed to introduce carbon-free metallurgy;

- the decarbonization level should be measured by the following process stages - the decarbonization level of furnace production and that of steel-making.

Application of robotized and unmanned equipment creates considerable opportunities to increase efficiency of production and industrial security due to unmanned shaft sinking, application of drones to assessing mining operations at open pits; application of robots to extracting furnace sinter, sampling liquid steel, controlling chemical composition of steel in melting machines, applying a fireproof coat; application of unmanned cranes and other machines to basic process stages controlled by artificial intelligence, etc. That is why, a set of indicators assessing security of economic interests of enterprises should be complemented with application of robotized and unmanned machines and the level of expenses for their supply and maintenance.

\section{Conclusions.}

Thus, the suggested methods of forming and providing security of enterprises' strategic economic interests envisage integration of the following components and elements: management levels (operational and strategic); time horizons of management (the past, the present and the future); resource supply components (traditional resources and resources of highlevel strategic status); and conditions of the objective reality (hazards (threats), stakeholders' demands, opportunities of the business environment). Content-related future transformations of environment parameters of mining and metallurgical enterprises determine the objective necessity to form a new set of indicators that expands the range of conventional business analytics in security studies aimed at timely implementation of managerial actions to achieve strategic correspondence of available resources and processes to future environment parameters. These indicators are formed on the basis of global trends determining conditions of forming and providing economic security till 2030 including deindustrialization of the world economy and regional transformation of consumer demands (indicators of export increase on promising markets), total digitalization of economic activity (indicators of business digitalization, the cyber-security level, etc.); decarbonization of production (the level of using limitations for carbon emissions, the level of current expenditures to buy carbon quotas, etc.) and carbon-free metallurgy (technological indicators of the level ofreadiness to partial transition), and indicators of processibility of basic groups of enterprise stakeholders.

\section{References}

Ajdari, B. and Asgharpour, S. (2011), "Human security and development, emphasizing on sustainable development", Procedia Social and Behavioral Sciences, no. 19, pp. 41-46, doi.org/10.1016/j.sbspro.2011.05.105

Biloshkurska, N. V. (2013), "Economic and organizational mechanism of formation of economic security of the enterprise: principles of construction, functions, structure", Ekonomika ta derzhava, no. 12, pp. 24-29.

Chumarin, I. (2003), "Personnel security”, Kadry predpriyatiya, no. 3, pp. 89-94.

Giannopoulos, G., Filippini, R. and Schimmer, M. (2012), Risk assessment methodologies for critical infrastructure protection, Part I: A state of the Art, Joint Research Centre of Institute for the Protection and Security of the Citizen, Luxembourg, $70 \mathrm{p}$.

Hrynko, T. V. and Lysenko, L. V. (2014), "Factors of formation of economic security of the enterprise», Visnyk Dnipropetrovskoho universytetu, Seriia "Ekonomika", vol. 8(3), pp. 85-90.

Ianioglo, A. and Polajeva, T. (2016), "Origin and definition of the category of economic security of enterprise", Business and Management 2016, The 9th International Scientific Conference proceedings, Vilnius, Lituania, May 12-13, 2016, available at: http://bm.vgtu.lt/index.php/verslas/2016/\%20paper/viewFile/47/47 (Accessed 25 April 2019). 
Kurhuzenkova, L. A (2016), "Economic security of the enterprise: the essence and factors of formation of its corresponding level“, Ekonomichnyi visnyk Zaporizkoi derzhavnoi inzhenernoi akademii, vol. 2, pp. 2933.

Lebedko, S. A. (2017), "Formation of a mechanism for ensuring the economic security of transport enterprises", Ekonomika ta derzhava, no. 8/2017, pp. 89-94.

Liashenko, O. M. (2015), Kontseptualizatsiia upravlinnia ekonomichnoiu bezpekoiu pidpryiemstva [Conceptualization of economic security management of the enterprise], NISD, Kyiv, Ukraine, 348 p.

Mishchuk, Ie. V. (2018), "Efficiency of ensuring economic security and its components (on the example of ecological safety)", Internauka, Seriia: "Ekonomichni nauky”, no. 11(92), pp. 14-25.

Putsenteilo, P. and Humeniuk, O. (2017), "The main aspects of forming an effective system of economic security of the enterprise", Ekonomichnyi dyskurs, vol. 2, pp. 37-47.

Suhorukova, T. (1998), "Problems of economic security of the enterprise", Biznes Inform, no. 4, pp. 61-65.

Tambovcev, V. L. (1994), "Object of economic security of Russia”, Voprosy ekonomiki, no. 12, pp. 45-53.

Tambovcev, V. L. (1995), "Economic security of economic systems: the structure of the problem", Vestnik Moskovskogo gosudarstvennogo universiteta, Seriya 6, Ekonomika, no. 3, pp. 3-24.

Tamošiūnienè, R. and Munteanu, C. (2015), “Current research approaches to economic security”, The 1 st International Conference on Business Management, Universitat Politècnica de València, July 2-3, 2015. doi: http://dx.doi.org/10.4995/ICBM.2015.1537, available at: http://ocs.editorial.upv.es/index.php/\%20ICBM/1ICBM/paper/viewFile/1537/723 (Accessed 29 April 2019).

The Aspen Institute (2018), “Financial Security Program”, available at: https://www.aspeninstitute.org/programs/financial-security-program/ (Accessed 21 April 2019).

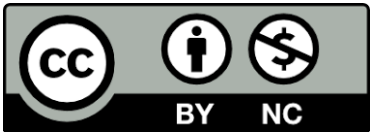

Цей твір ліцензовано на умовах Ліцензії Creative Commons «/з Зазначенням Авторства - Некомерційна 4.0 Міжнародна» (CC BY-NC 4.0). This is an open access journal and all published articles are licensed under a Creative Commons "Attribution-NonCommercial 4.0 International" (CC BY-NC 4.0). 